\title{
Nükleer Silahların Yasaklanması Andlaşması'nın Nükleer Silahsızlanma Çabaları ve Andlaşmalar Hukuku Çerçevesinde Değerlendirilmesi
}

\author{
Evaluation of the Treaty on the Prohibition of Nuclear Weapons within \\ the Framework of Nuclear Disarmament Efforts and Treaty Law
}

\section{Nergiz Emir ${ }^{*}$ (iD)}

\section{öz}

Nükleer Silahların Yasaklanması Andlaşması, 22 Ocak 2021 tarihinde yürürlüğe girmiştir. Bu andlaşma, nükleer silahları yasaklayan bağlayıcı bir uluslararası hukuk kaynağıdır. Ne var ki uluslararası andlaşmalar, pacta tertiis ilkesi çerçevesinde sadece tarafları için hak ve yükümlülük doğurmaktadır. Dolayısıyla, bu andlaşmanın nükleer silahsızlanmaya ne ölçüde katkıda bulunabileceği tartışmalıdır. Makale, Nükleer Silahların Yasaklanması Andlaşması’nın nükleer silahsızlanma çabalarına muhtemel katkısını ve uluslararası andlaşmalar hukuku bakımından ilgili andlaşmanın etkisini değerlendirmektedir.

Anahtar Kelimeler: Nükleer Silahların Yasaklanması Andlaşması, Silahsızlanma, Nükleer Silahsızlanma Çabaları, Pacta Tertiis İlkesi, Andlaşmalar Hukuku

\section{ABSTRACT}

The Treaty on the Prohibition of Nuclear Weapons entered into force on $22^{\text {nd }}$ January 2021 . This treaty is a binding source of international law which ban to nuclear weapons. However, international treaties create rights and obligations only for parties within the framework of the principle of pacta tertiis. Therefore, it is controversial to what extent this treaty could contribute to nuclear disarmament. The article evaluates the expectative contribution to nuclear disarmament efforts of the Treaty on the Prohibition of Nuclear Weapons and the impact of related treaty in terms of international treaty law.

Keywords: Treaty on the Prohibition of Nuclear Weapons, Disarmament, Efforts to Nuclear Disarmament, Principle of Pacta Tertiis, Treaty Law

\footnotetext{
* Dr. Öğr. Üyesi, Anadolu Üniversitesi Hukuk Fakültesi Milletlerarası Hukuk Anabilim Dalı, Sorumlu Yazar/Correspondence Author: Nergiz Emir
}

E-posta/E-mail: nergizdemirer@anadolu.edu.tr 


\section{Giriş}

Nükleer silahlar, dünyadaki en tehlikeli silahlar olup hem insanlı̆̆ın geleceği hem de çevresel felaketler bakımından önemli bir tehdit oluşturmaktadır. Bu tehlikeden korunmanın en önemli yolu kuşkusuz nükleer silahlardan arındırılmış bir dünyanın kurulmasıdır. Nükleer silahlar ilk kez 1945 yılında Hiroşima ve Nagazaki’de kullanılmış ve Birleşmiş Milletler (BM) 1946 yılında atom enerjisinin keşfine ilişkin sorunlara dair bir Komisyon kurmuştur. Uluslararası hukukta nükleer silahların yayılmasının önlenmesi amacıyla çeşitli andlaşmalar yapılmıştır ${ }^{1}$. Ancak nükleer silahları tamamen yasaklayan Nükleer Silahların Yasaklanması Andlaşması (NSYA), 2021 yılının ilk ayında yürürlüğe girmiştir.

NSYA ile birlikte uluslararası hukukta nükleer silahları yasaklayan bir uluslararası andlaşmanın yapılmasının mümkün olduğu görülmüş ve bu andlaşma pek çok uluslararası hukuk katılımcısının da katkısıyla devletler tarafından kabul edilerek uluslararası hukuk kaynağı haline gelmiştir. Ne var ki, NSYA'ya taraf olan devletlerden hiçbiri nükleer silahlara sahip değildir ${ }^{2}$ ve pacta tertiis ilkesi gereğince uluslararası andlaşmalar sadece tarafları için hak ve yükümlülük doğurmaktadır ${ }^{3}$. Ancak uluslararası hukukta bu kuralın istisnaları bulunmakta ve uluslararası andlaşmaların üçüncü devletlere etkisi tartışılmaktadır ${ }^{4}$.

Bu makalede, öncelikle NSYA’nın nükleer silahsızlanma çabalarındaki konumunu belirlenecek ve böyle bir andlaşmanın yapılabilmesini sağlayan dinamikler üzerinde durulacaktır. Daha sonra, NSYA’yı imzalayan ya da onaylayan devletlerin hiçbirinin nükleer silahlara sahip olmadı̆̆ göz önüne alındığında ilgili uluslararası andlaşmanın nükleer silahlara sahip olan (ancak andlaşmaya taraf olmayan ve dahası taraf olma niyeti de bulunmayan) devletlere uygulanıp uygulanamayacağı uluslararası andlaşmalar hukuku bakımından ele alınacaktır.

\section{ULUSLARARASI HUKUKTA NÜKLEER SILAHSIZLANMA ÇABALARI}

Uluslararası hukukta nükleer silahların açıkça yasaklandığı için andlaşma olan NSYA, 22 Ocak 2021'de yürürlüğe girmiştir. Bu andlaşmanın yürürlüğe gitmesi nükleer silahsızlanma çabaları bakımından önemli bir aşamadır. Uluslararası hukuk bakımından bundan önceki diğer bir önemli aşama ise, Nükleer Silahların Yayılmasının Önlenmesi Andlaşması’nın (NSYÖA) 1970 yılında yürürlüğe girmesidir ${ }^{5}$. Bu iki uluslararası andlaşma arasında yürürlüğe girmeleri bakımından yaklaşık elli yıllık bir zaman dilimi söz konusudur ve bu süre boyunca dünyanın siyasi yapısı büyük ölçüde değişmiştir. Öte yandan, bu iki andlaşma arasında hem içerik hem de andlaşmaların oluşturulma

\footnotetext{
United Nations Office for Disarmament Affairs, https://www.un.org/disarmament/wmd/nuclear/ (26.02.2021).

2 United Nations Treaty Collection, https://treaties.un.org/Pages/ViewDetails.aspx?src=TREATY\&mtdsg_no=XXVI9\&chapter=26 (26.02.2021).

3 Pazarcı, Hüseyin: Uluslararası Hukuk Dersleri I. Kitap, Gözden Geçirilmiş 15. Bası, Turhan Kitabevi, Ankara 2021, s. 183.

4 Akkutay, Berat Lale: Uluslararası Andlaşmaların Üçüncü Devletlere Etkisi, Adalet Yayınevi, Ankara 2020, s. 19.

5 Pedrazzi, Marco: “The Treaty on the Prohibition of Nuclear Weapons: a Promise, a Threat or a Flop?", The Italian Yearbook of International Law Online, 27(1), 2018, s. 215.
} 
süreci bakımından önemli farklar bulunmaktadır. Makalenin bu kısmında nükleer silahsızlanmaya ilişkin iki temel uluslararası hukuk kaynağı arasındaki farklara da değinilecektir.

Nükleer silahsızlanma çabalarında NSYÖA ve NSYA andlaşmaları dikkat çekici olsa da uluslararası hukukbakımından nükleer silahsızlanma çabalarını dahageriye götürmek mümkündür. Silahsızlanma yolundaki ilk girişime örnek olarak BM Genel Kurulu tarafından 24 Ocak 1946'da kurulan Komisyon $^{6}$ gösterilmiştir $^{7}$. Ancak bu Komisyon sadece üç yll sınırlı bir faaliyet gösterebilmiştir. NSYÖA yürürlüğe girene kadar, çeşitli devletler teknolojik gelişmelere uyum sağlamış ve nükleer silah üretimine başlamışlardır. Dolayısıyla NSYÖA, nükleer silah sahibi devletler ile buna sahip olmayan devletler arasında bir ayrım yapmış ve temelde nükleer silah sahibi devletlerin, nükleer silah sahibi olmayan devletlere nükleer silah transferini yasaklamıştır ${ }^{8}$. NSYA ise, nükleer silahların ortadan kaldırılması konusunda geleneksel devlet merkezli silahsızlanmadan uzaklaşmış ve konuyu insancıl silahsızlanma şeklinde farklı bir açıdan ele almıştır9 .

Uluslararası hukukta silahsızlanmanın gelişimi konusunda doktrinde pek çok çalışma bulunmaktadır. $\mathrm{Bu}$ makale kapsamında nükleer silahsızlanma, uluslararası hukuk bakış açısıyla sınırlı olarak ele alınacak ve NSYA’nın nükleer silahsızlanma bakımından ortaya çıkardığı yenilikler üzerinde durulacaktır. Uluslararası bir andlaşma olarak NSYẢnın nükleer silahsızlanmaya katkı sunup sunamayacağı uluslararası hukukun normatif sınırları çerçevesinde değerlendirilecektir. Bu nedenle, nükleer silahların ilk kez kullanılmasından bu yana devam eden silahsızlanma arayışının dönüşümü incelenerek bir sonraki kısımda ele alınacak olan andlaşmalar hukuku bakımından NSYA’nın değerlendirilmesine hazırlık yapılmış olacaktır.

\section{A. NÜKLEER SILAHLAR SORUNU VE ILK ÇÖZÜM ARAYIŞLARI}

Nükleer silahlar, yıkıcı güçlerini atom çekirdeklerinin parçalanmasından ya da birleşmesinden elde eden patlayıcılar şeklinde tanımlanmaktadır ${ }^{10}$. Nükleer silah sorununun bilimsel ve teknik kısmı bir tarafa bırakılırsa uluslararası hukuk bakımından önemli olan bu silahların kullanımının ortaya çıkardığı sonuçlardır. Zira nükleer silah kullanımı hem insancıl hukuk kurallarını hem de uluslararası çevre hukukunu ilgilendiren olumsuz sonuçlara neden olmaktadır ${ }^{11}$. Bu bağlamda, nükleer silah

6 Atom Enerjisinin Keşfi ile Ortaya Çıkan Sorunların Çözümü İçin Komisyon Kurulması, https://www.un.org/ga/search/ view_doc.asp?symbol=A/RES/1(I) (28.02.2021).

7 Arman, Perçem: “2017 Nükleer Silahların Yasaklanması Antlaşması: Amaçladığını Başarabilir Mi?”, Dokuz Eylül Üniversitesi Hukuk Fakültesi Dergisi, Prof. Dr. Durmuş TEZCAN’a Armağan, 21(Özel Say1), 2019, s. 1909; Denk, Erdem: "Bir Kitle İmha Silahı Olarak Nükleer Silahların Yasaklanmasına Yönelik Çabalar", Ankara Üniversitesi SBF Dergisi, 66(3), 2011, s. 100.

8 Kadelbach, Stefan: "Nuclear Weapons and Warfare", R Wolfrum (ed), The Max Planck Encyclopedia of Public International Law Volume VII, Oxford University Press, Oxford 2012, s.878.

9 Docherty, Bonnie: "A 'Light for All Humanity': the Treaty on the Prohibition of Nuclear Weapons and the Progress of Humanitarian Disarmament”, Global Change, Peace \& Security, 30(2), 2018, s. 164.

10 Kadelbach, s. 873.

11 Güneysu, Gökhan: Çevrenin Silahlı Çatışmalar Esnasında Korunması, Adalet Yayınevi, Ankara 2014, s. 168. 
kullanımının sonuçlarını bir kere deneyimleyen uluslararası toplumun bu alanı düzenleme çabası kaçınılmaz bir sonuçtur.

Nükleer silahlar, Amerika Birleşik Devletleri (ABD) tarafından ilk kez kullanıldığı 1945 yılından itibaren, uluslararası andlaşmalar ile kontrol altına alınmaya çalışılmış olsa da hukuki düzenlemeler içinde bulunulan dönemin siyasi atmosferine göre şekil almıştır. Zira bu dönemde, diğer devletler de nükleer silah teknolojisine katılmaya başlamıştır. Sovyet Sosyalist Cumhuriyetler Birliği (SSCB), 1949 yllında dünyanın ikinci nükleer silah sahibi devleti olmuştur ${ }^{12}$. 1952'de Birleşik Krallık, 1960'ta Fransa ve 1964'te Çin nükleer silah geliştirmiş devletler arasına girmiştir ${ }^{13}$. Böylece Güvenlik Konseyi’nin beş daimi üyesi, 1960 'l y ylların ortasında nükleer silahlara sahip olmuştur. Günümüzde Güvenlik Konseyỉnin daimi üyesi olan bu devletler dışında; Hindistan, Pakistan, İsrail ve Kuzey Kore’nin nükleer silahlara sahip olduğu bilgisi yer almaktadır ${ }^{14}$.

Nükleer silahlanma sorunun ortaya çıkışı ve devletlerin bu teknolojiye sahip olma hızı çerçevesinde; 1945 yılında "nükleer çağ" olarak isimlendirilen yeni bir dönemin başladığı ve halen devam eden bu dönemde nükleer silahların yayılması ile silahsızlanma çabalarının birlikte yürüdügü görülmektedir ${ }^{15}$. Kuşkusuz NSYÖA, 1970 yllında yürürlüğe girdiğinde yirmi beş ylllık sorunu geçici olarak düzenleme altına almıştır. Ancak bu andlaşma yürürlüğe girene kadar, atomun barışçl amaçlarla kullanılması için Uluslararası Atom Enerjisi Ajansı (UAEA) 1957 yılında kurucu andlaşmasının yürürlüğe girmesiyle birlikte kurulmuştur ${ }^{16}$. UAEA, günümüzde hala etkin bir şekilde varlığını sürdüren uluslararası bir örgüt olmakla birlikte faaliyet alanı nükleer silahsızlanmadan ziyade nükleer teknolojinin kullanımına ilişkindir.

\section{B. NÜKLEER SILAHLARIN YAYILMASININ ÖNLENMESI ANDLAŞMASI}

\section{Andlaşmanın Genel Çerçevesi ve Nükleer Silahsızlanmaya Etkisi}

NSYÖA, nükleer silahların kontrolüne ilişkin mevcut sistemi kurucu bir nitelik taşımaktadır ${ }^{17}$. NSYÖA, nükleer silahların yayılmasının önlenmesine odaklı bir sistem kurmuş ve temelde Ocak 1967’ye kadar bir nükleer silah yeteneği geliştirmemiş olan herhangi bir devletin bunu yapmasını önlemeyi amaçlamıştır. Böylece andlaşma kapsamında ABD, SSCB, Birleşik Krallık, Fransa ve Çin nükleer silah sahibi devletler olma statüsünü kazanmıştır. Hindistan, Pakistan ve İsrail ise, NSYÖA’ya hiç taraf olmamış ve Kuzey Kore ise 2002'de bu andlaşmadan çekilmiştir ${ }^{18}$.

12 Russia and Nuclear Weapons, https://www.nti.org/learn/countries/russia/nuclear/ (28.02.2021).

13 Nuclear-Armed States, https://www.icanw.org/nuclear_arsenals (28.02.2021).

14 Nuclear-Armed States, https://www.icanw.org/nuclear_arsenals (28.02.2021).

15 Datan, Merav / Scheffran, Jürgen: “The Treaty is Out of the Bottle: The Power and Logic of Nuclear Disarmament”, Journal for Peace and Nuclear Disarmament, 2(1), 2019, s. 115.

16 UAEA Statüsü, https://treaties.un.org/doc/Publication/UNTS/Volume\%20276/volume-276-I-3988-English.pdf (28.02.2021).

17 Arman, s. 1914.

18 Hanson, Marianne: “The Future of the NPT", Australian Journal of International Affairs, 59(3), 2005, s. $302,303$. 
NSYÖA'ya hâlihazırda 191 devlet taraf olsa da aslında bu andlaşma Soğuk Savaş yıllarının bir çıktısıdır ${ }^{19}$. Buna rağmen NSYÖA, çok sayıda devletin de taraf olması bakımından da belirli bir normatif değer kazanmış ve hukuki bir çerçeve çizmiştir ${ }^{20}$. Üstelik NSYÖA, uluslararası hukukta silahsızlanmayı düzenleyen evrensel düzeyde bir uluslararası andlaşmadır ve 1995 yılında süresiz hale getirilmiştiri ${ }^{21}$. NSYÖA, nükleer silah sahibi devletlerin faaliyetlerini kontrol altına almaya çalışırken nükleer silah sahibi olmayan devletlerin nükleer silahlara sahip olmalarını engellemeye yönelik bir andlaşmadır ve tam bir nükleer silahsızlanma için taraflara iyiniyetli müzakereler yapma yükümü yüklemiştir ${ }^{22}$.

NSYÖA’da yer alan, nükleer silah sahibi olmayan devletlerin bu silahları edinmemesine ilişkin

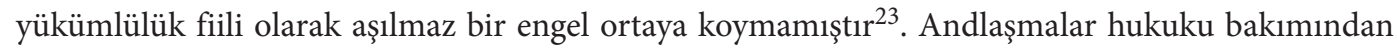
NSYÖA'da yer alan bu hüküm sadece andlaşmaya taraf olan devletler için hüküm ve sonuç doğuracaktır. Dolayısıyla Hindistan, Pakistan, İsrail ve Kuzey Kore gibi ülkeler bu andlaşma çerçevesinin dışında nükleer silahlara sahip olmaya devam etmektedir ${ }^{24}$. Bu durum, andlaşmanın etkin olarak uygulanmasına zarar verdiği gibi nükleer silahların yayılmasının kontrolünü sağlamaya çalışırken nükleer silah sahibi olmayan devletlerin bu teknolojiye erişmesini yasaklamaktadır ${ }^{25}$.

\section{Nükleer Silahların Tehdit ve Kullanımının Hukuka Uygunluğuna Dair Danışma Görüşü26}

Bu Danışma Görüşü, BM Genel Kurulu’nun 1994 yılında Uluslararası Adalet Divanı’na (Divan) yöneltmiş olduğu bir soru üzerine ortaya çıkmıștır. Divan, nükleer silah kullanımının uluslararası insancıl hukuka aykırı olduğunu belirtmekle birlikte meşru müdafaa durumunda bu silahları kullanmanın hukuku aykırı olup olmadığı konusunda kesin bir sonuca varılamadığını ifade etmiştir. Divan, nükleer silahsızlanma girişimlerinin etkili müzakerelerle sürdürülmesi yükümlülüğüne de dikkat çekmiştir ${ }^{27}$.

Bu Danışma Görüşü kapsamında nükleer silahların meşruluğu sorununa ilişkin çeşitli yorumlar yapılmışolsa da Divan’n yaklaşımı genel olarak nükleer silah kullanımını meşru bulmama yönündedir ${ }^{28}$. Ancak Divan, nükleer silah kullanımına ya da tehdidine ilişkin ne konvansiyonel uluslararası hukukta

19 Docherty, s. 170.

20 Hanson, s. 314.

21 Tuzmukhamedov, Bakhtiyar: "Disarmament", R Wolfrum (ed), The Max Planck Encyclopedia of Public International Law Volume III, Oxford University Press, Oxford 2012, s. 152, 156.

22 Treaty on the Non-Proliferation of Nuclear Weapons, http://disarmament.un.org/treaties/t/npt/text (02.03.2021).

23 Tuzmukhamedov, s. 156.

24 Bagheri, Saeed: Uluslararası İnsancıl Hukuk ve Nükleer Silahlar, Adalet Yayınevi, Ankara 2015, s. 90.

25 Bagheri, s. 106.

26 Legality of the Threat or Use of Nuclear Weapons, Advisory Opinion, I.C.J. Reports 1996, p. 226. https://www.icj-cij.org/ public/files/case-related/95/095.199.60708-ADV-01-00-EN.pdf (03.03.2021).

27 Legality of the Threat or Use of Nuclear Weapons, s. 266, 267.

28 Uzun, Elif: "Milletlerarası Adalet Divanının Nükleer Silahların Tehdidi veya Kullanımının Meşruiyeti İle İlgili 1996 Tarihli İstişari Mütalaasına İnsancıl Hukuk Açısından Bir Bakış”, Erzincan Hukuk Fakültesi Dergisi, 7(3), 2003 , s. 586. 
ne de örf ve adet hukukunda kapsamlı ve evrensel bir yasak olmadığına dikkat çekmiştir ${ }^{29}$. Doktrinde nükleer silah tehdidi ya da kullanımının "tam bir nükleer silahsızlanmaya ilişkin özel bir andlaşmayla ortadan kaldırılabileceği” ifade edilmiştir ${ }^{30}$. Dolayısıyla nükleer silahsızlanma çabalarına ilişkin önemli bir hamle olan NSYA’nın ortaya çıkışı ve kapsamı önemli bir gelişmedir.

\section{NÜKLEER SILAHLARIN YASAKLANMASI ANDLAŞMASI}

\section{Andlaşmanın Oluşturulma Süreci ve Önemli Gelişmeler}

Devletler, uluslararası örgütler ve hükümet-dışı kuruluşlar insancıl silahsızlanmayı nükleer silahlar bakımından 2010 yılında yeni bir bakış açısıyla ele almaya başlamıştır. Böylece nükleer silahsızlanmanın insancıl boyutunun önemi vurgulanarak uluslararası toplum harekete geçirilmiştir $^{31}$. Nükleer Silahların Tamamen Ortadan Kaldırması için Uluslararası Kampanya ${ }^{32}$ (Uluslararası Kampanya), ilk ofisini 2006'da açmış bir hükümet dışı kuruluş olarak kurulmasından itibaren nükleer silahsızlanmayı teşvik eden bir uluslararası andlaşma yapma amacını taşımıştır ${ }^{33}$. Uluslararası Kampanya, 2010 ile 2012 yılları arasında önemli değişiklikler geçirmiş ve bu sürecin sonunda nükleer silahların yasaklanmasını açıkça talep etmeye başlamıştır ${ }^{34}$. Uluslararası Kampanya, 2013’ten sonra nükleer silahsılanmaya ilişkin önemli konferanslar düzenlemiş ve bu konferanslara pek çok devletin yanı sıra BM de katılmıştır ${ }^{35}$. Uluslararası Kampanya, nükleer silahsızlanmayı teşvik etmedeki çabaları ve bunun küresel düzeydeki önemi nedeniyle 2017 Nobel Barış Ödülü’ne layık görülmüştür ${ }^{36}$.

Uluslararası Kampanya’nın başını çektiği konferanslar, nükleer silahsızlanma konusunda BM’nin harekete geçirilmesinde etkili olmuştur. Özellikle Uluslararası Kampanya tarafından nükleer silahların insancıl etkileri konulu Viyana’da 2014 yılında gerçekleştirilen konferansta kabul edilen insancıl teminat 127 devlet tarafından imzalanmıştır ${ }^{37}$. Bu teminat, 2015 yılında BM Genel Kurul kararı ile kabul edilmiştir ${ }^{38}$. Bunun yanında başka bir BM Genel Kurul kararı ile Açık Uçlu Çalışma Grubu kurularak çok taraflı nükleer silahsızlanma müzakerelerinin yürütülmesine

29 Legality of the Threat or Use of Nuclear Weapons, s. 266.

30 Tütüncü, Ayşe Nur: "Nükleer Silâhların Kullanımının Yasaklanması Sorunu”, Anadolu Üniversitesi Sosyal Bilimler Dergisi, 4(2), 2004, s. 14.

31 Docherty, s. 164.

32 International Campaign to Abolish Nuclear Weapons (ICAN), hakkında detaylı bilgi için: https://www.icanw.org/the campaign (06.03.2021).

33 Gibbons, Rebecca Davis: "The Humanitarian Turn in Nuclear Disarmament and the Treaty on the Prohibition of Nuclear Weapons", the Nonproliferation Review, 25(1-2), 2018, s. 14.

34 Gibbons, s. 18, 19.

35 Arman, s. 1920.

36 Datan / Scheffran, s. 118.

37 Humanitarian Pledge, https://www.icanw.org/history_of_the_tpnw (07.03.2021).

38 Arman, s. 1921; UN General Assembly, A/RES/70/48, https://www.un.org/en/ga/search/view_doc.asp?symbol=A/ RES/70/48 (07.03.2021). 
katkıda bulunabilecek tavsiye kararları alabileceği belirtilmiştir. ${ }^{39}$ Açık Uçlu Çalışma Grubu’nun 2016'daki nihai raporu ile 2017 yllında BM Genel Kurulu’nun nükleer silahların tamamen ortadan kaldırılması için bir konferans yapması önerilmiş ve böylece NSYA’nın imzalanacağı konferanslar New York’ta gerçekleştirilmiştir ${ }^{40}$. Dolayısıyla NSYA’nın ortaya çıkmasında hükümet dışı kuruluşlar ile devletlerin birlikte inisiyatif almasının ve uluslararası bir örgüt olarak BM’nin önemli bir etkisinin olduğu görülmektedir ${ }^{41}$.

NSYA, 7 Temmuz 2017 tarihinde New York'ta 122 devletin olumlu oyu ile kabul edilmiş ve 20 Eylül 2017'de BM Genel Sekreteri tarafından imzaya açılmıştır. NSYA, 22 Ocak 2021'de uluslararası bir andlaşma olarak yürürlüğe girmiştir ${ }^{42}$. Böylece nükleer silahların kullanılmasını açıkça yasaklayan ilk uluslararası andlaşma ortaya çıkmış olsa da nükleer silahların mevcudiyeti üzerinde nasıl bir etkiye sahip olacağı hususu tartışmalıdır. Zira nükleer silah sahibi devletlerin henüz andlaşmaya ilişkin oylamanın hemen ardından yaptığı açıklamalar ${ }^{43}$ andlaşmanın pek çok devlet tarafından onaylanmış olsa bile uygulamada bir değişiklik ortaya koyamayacağını düşündürmektedir ${ }^{44}$. Buna rağmen andlaşmanın kural koyan bir düzenleme niteliğinde olması ve nükleer silahsızlanmaya yeni bir ivme kazandırması nedeniyle iyimser değerlendirmelerle ele alınması da söz konusudur ${ }^{45}$.

\section{Andlaşmanın Kapsamı ve Hükümleri}

NSYA $^{46}$ giriş bölümü ve buna ilaveten 20 maddeden oluşan bir uluslararası andlaşmadır. Andlaşmanın giriş bölümünde uzunca bir paragraf yer almakta ve her bir paragrafta andlaşmanın amaçlarına ve ilkelerine ilişkin değerlendirmelerden bahsedilmektedir. Bu bağlamda, hemen ilk paragrafta NSYA'nın BM Şartı’nda belirtilen amaç ve ilkelerin gerçekleşmesine katkıda bulunma hedefinde olduğu belirtilmiştir. Bunun devamında nükleer silah kullanımının yıkıcı sonuçlarına dikkat çekilerek bu tür silahların hiçbir surette kullanılmamasının tek yolunun nükleer silahların tamamen ortadan kaldırılması olduğu ifade edilmiştir. Bu kısımda nükleer uluslararası insancıl hukuk ve uluslararası insan hakları hukuku dahil olmak üzere tüm devletlerin her zaman geçerli uluslararası hukuk kurallarına uymaları gerektiğine dikkat çekilmiştir. Ayrıca NSYÖA’nın uluslararası barış ve güvenlik ile nükleer silahsızlanma bakımından önemine dikkat çekilerek bu andlaşmanın etkili bir biçimde uygulanmasını onaylanmıştır. Andlaşmanın giriş kısmı genel olarak

39 UN General Assembly, A/RES/70/33, https://undocs.org/pdf?symbol=en/a/res/70/33 (07.03.2021).

40 Pedrazzi, s. 219.

41 Docherty, s. 174.

42 Overview of TPNW, https://www.un.org/disarmament/wmd/nuclear/tpnw/ (07.03.2021).

43 ABD, Birleşik Krallık ve Fransa andlaşmaya hiçbir zaman taraf olmayı düşünmediklerini belirten ortak bir bildiri yayımlamıştır. NSYA'nın mevcut uluslararası güvenliği görmezden geldiğini, nükleer caydırıcılıkla uyumsuz olduğunu ve NSYÖA ile kurulan sistemi zayıflatabileceğini ileri sürmüşlerdir. https://www.nti.org/learn/treaties-and-regimes/ treaty-on-the-prohibition-of-nuclear-weapons/ (07.03.2021).

44 Arman, s. 1940.

45 Rietiker, Daniel: “New Hope for Nuclear Disarmament or 'Much Ado About Nothing?': Legal Assessment of the New "Treaty on the Prohibition of Nuclear Weapons" and the Joint Statement by the USA, UK, and France Following its Adoption., Harvard International Law Journal, 59, 2017, s. 31.

Nükleer Silahların Yasaklanması Andlaşması, https://undocs.org/A/CONF.229/2017/8 (07.03.2021). 
değerlendirildiğinde, uluslararası toplumun nükleer silahsızlanma konusundaki niyetinin hukuk çerçevesinde birleștirilmesinin amaçlandığı görülmektedir.

Andlaşmanın 1. maddesinde nükleer silahlara ilişkin yasaklara yer verilirken 2, 3 ve 4 . maddelerde nükleersilahlarıortadan kaldırmayayönelikhükümlerden bahsedilmiştir. Bundan sonraki 16 maddede ise, andlaşmanın uygulanmasına ilişkin hükümler yer almaktadır. Andlaşmanın 1. maddesinde, taraf devletlerin hiçbir koşul altında andlaşma ile yasaklanan eylemleri gerçekleştirmeyeceği hüküm altına alınmıştır. Bu kapsamda 1. maddenin ilk fikrasında, nükleer silah ya da patlayıcı araçların geliştirilmesi, test edilmesi, üretilmesi, elde edilmesi, bulundurulması ve stoklanması mutlak olarak yasaklanmıştır. Öte yandan, sonraki fikralarda nükleer silahların devredilmemesi, kullanılmaması ya da kullanmakla tehdit edilmemesi gibi pek çok yasaklayıcı hükme yer verilmiştir.

Andlaşmanın 2. maddesinde NSYA'ya taraf olan devletlerin bulunması gereken bildirimler yer almaktadır. Andlaşmanın 3. maddesinde ise, taraf devletlerin vermesi gereken güvenceler düzenlenmektedir. Bildirimler nükleer silah sahibi devletleri ilgilendirirken güvenceler nükleer silah sahibi olmayan devletlerle ilgili hükümler şeklinde değerlendirilebilecektir. Andlaşmanın 4. maddesinde nükleer silahların tamamen ortadan kaldırılmasına ilişkin alternatifler yer almaktadır. NSYA’nın 5. madde ile devam eden hükümleri daha ziyade andlaşmanın uygulanmasına yöneliktir. 12. maddede andlaşmanın taraflarının, taraf olmayan devletleri andlaşma ile bağlanmaya teşvik etmesi yani andlaşmanın evrenselleşmesi amacını taşımaları gerektiği belirtilmiştir. Diğer taraftan 16. madde ile andlaşmaya çekince ileri sürülebilmesi engellenmiş ve 17. madde ile andlaşmadan çekilmenin hüküm ve koşulları özel olarak düzenlenmiştir.

\section{ANDLAŞMALAR HUKUKU BAKIMINDAN NÜKLEER SILAHLARIN YASAKLANMASI ANDLAŞMASI}

Nükleer silahların yasaklanması konusunda çekince ileri sürülemeyen bir uluslararası andlaşma 2021 yılı itibariyle yürürlükte bulunmaktadır. Ne var ki, pacta tertiis ilkesi gereğince bu uluslararası andlaşma sadece kendisine taraf olan devletleri bağlamaktadır. Andlaşmalar hukuku çerçevesinde bu andlaşmanın bütün uluslararası hukuk kişilerini bağlayabilmesi için bir şekilde pacta tertiis ilkesinin istisnaları kapsamında değerlendirilebilmesi gerekmektedir. Aksi takdirde NSYA’nın normatif bir bakış açısıyla evrensel düzeyde bağlayıcı olduğunu ya da olabileceğini kabul etmek mümkün görünmemektedir.

Makalenin bu ikinci ana başlığında NSYA andlaşmalar hukuku çerçevesinde incelenecektir. Bu sayede ilgili andlaşmanın ilk ana başlıkta yer verilen nükleer silahsızlanmaya katkısının hukuki çerçevesi tespit edilebilecektir. Belirtmek gerekir ki, NSYA normatif olarak taraf olmayan devletleri bağlayacak nitelikte olmasa bile böyle bir andlaşmanın yapılmış olması devletleri ya da daha genel bir ifadeyle uluslararası toplumu alternatif bir nükleer silahsızlanma modeline yaklaştırmıştır. Ancak bu makale bakımından meselenin uluslararası hukukun asli bir kaynağı olan andlaşmalar çerçevesindeki etkinliği irdelenmektedir. 


\section{A. PACTA TERTiis ILKESI VE ISTISNALARI}

Andlaşmaların üçüncü kişiler bakımından hak ve yükümlülük doğurmaması uluslararası hukukta kabul edilen temel ilkelerden biridir ${ }^{47}$. Bu temel kuralı uluslararası hukukta geçerli kılan temel dayanak noktası ise, devletlerin bağımsızlığı ve egemen eşitliği ilkesidir ${ }^{48}$. Viyana Andlaşmalar Hukuku Sözleşmesi ${ }^{49}$ (VAHS), 34-38. maddelerinde andlaşmalar ve üçüncü devletler arasındaki ilişkiyi düzenlemiştir. VAHS’nin 34. maddesi, pacta tertiis ilkesini açıkça ortaya koymuş ve uluslararası andlaşmaların rızası olmadan üçüncü devletler için ne hak ne de yükümlülük yaratacağını belirtmiştir. Bu bağlamda, VAHS'de genel kuralın pacta tertiis ilkesi çerçevesinde kurulduğu açıkça ortadadır ${ }^{50}$.

VAHS’nin 35. ve 36. maddelerinde üçüncü devletlerin rızasıyla onlar için hak ve yükümlülüklerin söz konusu olabileceği düzenlenmiştir. Andlaşmanın 35. maddesi üçüncü devletler için yükümlülükler öngören andlaşmaları düzenlerken üçüncü devletin ilgili yükümlülüğü "açıcça yazılı bir şekilde" kabul etmesi gerektiğini belirtmiştir. 36. maddede de, üçüncü devletlerin rızasıyla onlar için haklar öngören andlaşmaların yapılabileceği ifadesi yer almaktadır. Bu düzenlemelerin her ikisi de üçüncü devletlerin rızaları dahilinde hak ve yükümlülükler ortaya çıkarabilmektedir. VAHS’nin 37. maddesi ise, bu hak ya da yükümlülüklerin geri alınması veya değiştirilmesine ilişkin bir hükümdür.

VAHS'nin 38. maddesi ise, bir andlaşmada yer alan kuralların aynı zamanda uluslararası örf ve adet hukuku kuralı olması durumunda andlaşmaya taraf olmayan devletleri de bağlayacağını hüküm altına almıştır. Ancak böyle bir durumda andlaşmanın kendisinin üçüncü devletler için bağlayıcı sonuç doğurması söz konusu değildir ${ }^{51}$. Andlaşma hükümleri aynı zamanda uluslararası örf ve adet hukuku kapsamında değerlendirildiği için üçüncü devletler üzerinde etkili olabilmektedir.

NSYA’nın nükleer silah sahibi devletler üzerinde etkili olması hususunda üçüncü devletlerin rızası bulunmadığı için VAHS’nin 35. ve 36. maddelerinin uygulanabilmesi mümkün değildir. Bunun dışında NSYA'da yer alan hükümlerin uluslararası örf ve adet hukuku kuralı haline gelmesi durumunda, andlaşmaya taraf olmayan devletleri de bağlaması söz konusu olabilecektir. Ancak bu durumda da nükleer silah sahibi devletler, uluslararası örf ve adet hukuku içerisinde yer alan ve örf ve adet hukuku kuralından sıyrılmanın bir yolu olan 52 "1srarlı itiraz" kurumundan faydalanmamalıdır. ABD, Birleşik Krallık ve Fransa makalenin önceki kısımlarında belirtildiği gibi andlaşmada yer alan hükümlere karşı olduklarını içeren bir bildiri yayımlamışlardır. Dolayısıyla, NSYA’da yer alan nükleer

47 Akkutay, s. 24; Pazarcı, s. 183.

48 Toluner, Sevin: “'Objektif Hukuki Durum Yaratan Andlaşmalar’ Kavramı Gerekli Midir?”, Milletlerarası Hukuk ve Milletlerarası Özel Hukuk Bülteni, 25(1-2), 2005, s. 522.

49 Vienna Convention on the Law of Treaties done at Vienna on 23 May 1969. Entered into force on 27 January 1980. United Nations, Treaty Series, vol. 1155, p. 331. https://legal.un.org/ilc/texts/instruments/english/conventions/1_1_1969.pdf (11.03.2021); Türkçesi için: Kaya, İbrahim: Uluslararası Hukukta Temel Belgeler, 4. Baskı, Seçkin Yayıncılık, Ankara 2020, s. 66-111.

50 Aust, Anthony: Modern Treaty Law and Practice, 3. Edition, Cambridge University Press, London 2013, s. 227.

51 Aust, s. 230.

52 Öktem, Emre: Uluslararası Teamül Hukuku, Beta Yayınları, İstanbul 2013, s. 455. 
silahların yasaklanmasına ilişkin hükümlerin örf ve adet hukuku kuralı oluşturduğu kabul edilse bile nükleer silah sahibi devletlerin ısrarlı itirazı bu yasağın kendilerine uygulanmasına engel olacaktır ${ }^{53}$.

Uluslararası hukukun nükleer silahların yasaklanmasına ilişkin kuralları nükleer silah sahibi devletler için de bağlayıcı kabul edebilmesi için ya NSYẢnın objektif rejim yaratan bir andlaşma olarak kabul edilmesi ya da bu andlaşmada yer alan yasaklayıcı hükümlerin erga omnes etki doğurabilmesi gerekmektedir. Objektif rejim yaratan andlaşmalar, uluslararası hukukta oldukça tartışmalı olduğu gibi genel olarak kabul görmüş bir teori de ortaya koymamaktadır ${ }^{54}$. Andlaşmanın erga omnes etki doğurabilmesi için bu kuralların jus cogens nitelikte kabul edilmesi de mümkündür. Nükleer silahların yasaklanmasına ilişkin kuralların jus cogens kural haline gelmesi durumundan 1srarlı itirazcı devletlere de uygulanabilmesi mümkün olacaktır ${ }^{55}$. Makalenin bu kısmında NSYẢnın objektif rejim yaratan bir andlaşma olma niteliği ya da andlaşmada yer alan kuralların erga omnes yükümlülükler doğurup doğuramayacağı tartışılacaktır.

\section{B. OBJEKTIF REJIM YARATAN ANDLAŞMALAR}

Uluslararası andlaşmalar hukuku bakımından tartışmalı bir konu olan objektif rejim yaratan andlaşmalar, ilgili andlaşmaya taraf olmayan üçüncü devletleri de bağlamakta ve onlar için erga omnes yükümlülükler ortaya koymaktadır ${ }^{56}$. Bu andlaşmalar genel bir fayda söz konusu olduğu için istisnai olarak üçüncü devletlerin durumlarını etkileyebilmektedir ${ }^{57}$. Bu istisnai durumun ortaya çıkmasını sağlayan andlaşmalar genellikle bir devletin siyasal statüsü, belirli bir ülkenin tamamının ya da bir parçasının silahsızlandırılması ya da askersizleştirilmesi, uluslararası su yıllarından geçişi düzenleyen andlaşmalar ve bazı uluslararası örgütlerin uluslararası hukuk kişiliği şeklinde ifade edilmiştir ${ }^{58}$. NSYẢnın en azından konusu ve hükümleri bakımından bu kapsamda değerlendirilebilmesi söz konusu değildir.

Objektif rejim yaratan andlaşmalar hem konusu itibariyle hem de dönemin siyasi özellikleri nedeniyle 19. yüzyılda yapılmıştır. Ancak 21. yüzyılda uluslararası toplumun evrensel karakteri, devletlerin egemen eşitliği ilkesi ve iç işlerine müdahale yasağı objektif rejim yaratan andlaşmalara kuşkuyla yaklaşılmasına neden olmuştur ${ }^{59}$. İradeci uluslararası hukuk anlayışı, uluslararası andlaşmaya taraf olmayan ve ilgili andlaşmanın kendisi için hüküm ve sonuç doğurmasına zımni olarak da onay vermeyen bir uluslararası hukuk kişisine andlaşma hükümlerinin uygulanabilmesine karşı durmaktadır ${ }^{60}$.

53 Rietiker, s. 27

54 Akkutay, s. 193.

55 Rietiker, s. 27.

56 Romani, Carlos Fernández de Casadevante: "Objective Regime", R Wolfrum (ed), The Max Planck Encyclopedia of Public International Law Volume VII, Oxford University Press, Oxford 2012, s. 912.

57 Salerno, Francesco: “Treaties Establishing Objective Regimes", E. Cannizzaro (ed), The Law of Treaties Beyond the Vienna Convention, Oxford University Press, New York 2011, s. 226.

Akkutay, s. 117; Pazarcı, s. 189.

Romani, s. 914, 915.

Pazarcı, s. 189. 
Uluslararası hukukta objektif durum yaratan andlaşmalar çeşitli hukuki dayanaklar bu andlaşmaların geçerliliğini ortaya koymaya çalışmıştır. Bunlardan birisi objektif durum yaratan andlaşmaların hukuk yaratan andlaşmalarla benzer bir normatif değere sahip olduğunu ileri sürmektedir ${ }^{61}$. Bu yaklaşım objektif rejim yaratan andlaşmaları kamu hukuku teorileri çerçevesinde açıklamaktadır ${ }^{62}$. Objektif durum yaratan andlaşmaların hukuki dayanağını özel hukuk teorileri çerçevesinde açıklayan ve kamu hukuku ile özel hukuku birleştiren iki farklı yaklaşım daha bulunmaktadır ${ }^{63}$.

NSYA’nın objektif rejim yaratan bir andlaşma olduğunun kabul edilmesi durumunda bu andlaşmaya taraf olmayan üçüncü devletlere karşı ileri sürülebilmesi söz konusu olacaktır. Ne var ki, objektif rejim yaratan andlaşma teorisinin kendisi dahi uluslararası hukukta kabul görmüş bir durumda değildir. Üstelik NSYA’nın konusu, amaçları ve içerdiği hükümler bakımından objektif rejim yaratan bir andlaşma olma niteliği göstermediği ortadadır. NSYA'nın uluslararası bir andlaşma olarak bu andlaşmaya taraf olmayan nükleer silah sahibi devletlere uygulanabilmesinin bir aracı olarak objektif rejim yaratan andlaşma teorisi uygulanabilir görünmemektedir.

\section{ERGA OMNES YÜKÜMLÜLÜKLER}

Nükleer silahların yasaklanmasına ilişkin bir uluslararası hukuk kaynağının erga omnes yükümlülük olarak kabul edilmesi halinde tüm devletler için hüküm ve sonuç doğurması mümkün olacaktır. NSYẢnın jus cogens bir kural olarak kabul edilmesi neticesinde ya da başka bir biçimde erga omnes yükümlülük doğurup doğuramayacağı makalenin bu kısmında tartışılacaktır. Zira uluslararası hukukta nükleer silahların mutlak bir biçimde yasaklanabilmesinin tek yolu bu yasağın bütün uluslararası hukuk kişilerine karşı ileri sürülebilecek bir yükümlülük şeklinde ortaya çıkmasıdır.

Uluslararası hukukta erga omnes yükümlülükler ve bu yükümlülüklerin uluslararası hukuktaki yeri Barcelona Traction Davası'nda ${ }^{64}$ ele alınmıştır ${ }^{65}$. Divan, tüm devletlerin korunmasında hukuki bir menfaatinin bulunduğu bazı hakların korunmasının erga omnes yükümlülükler doğurduğunu belirtmiştir ${ }^{66}$. Ayrıca Divan, bu tür yükümlülüklerin temel insan haklarına ilişkin ilke kurallardan kaynaklandığını ifade etmiş ve çağdaş uluslararası hukukta saldırganlık ve soykırımın yasaklanması ile kölelik ve ırk ayrımcilığından korunmayı bu kapsamda değerlendirmiştir ${ }^{67}$.

Barcelona Traction Davası'na ilişkin karardan bir yıl önce VAHS kabul edilmiş ve jus cogens kavramı uluslararası hukukta ilk defa tanınmıştır ${ }^{68}$. Uluslararası hukukun emredici kuralları olan jus cogens

61 Salerno, s. 236.

62 Akkutay, s. 120.

63 Akkutay, s. 125-129.

64 Barcelona Traction, Light and Power Company, Limited, Judgment, I.C.J. Reports 1970, p. 3. https://www.icj-cij.org/public/files/case-related/50/050.197.00205-JUD-01-00-EN.pdf (20.03.2021).

Söyler, Yasin: "Barcelona Traction Davası ve Uluslararası Hukuka Etkisi”, Ankara Hacı Bayram Veli Üniversitesi Hukuk Fakültesi Dergisi, 19(3), 2015, s. 209.

66 Barcelona Traction, para. 33.

67 Barcelona Traction, para. 34.

68 Frowein, Jochen A: “Obligations Erga Omnes", R Wolfrum (ed), The Max Planck Encyclopedia of Public International 
ile çatışan andlaşma hükümleri VAHS’nin 53. ve 64. maddelerine göre geçersizdir. Jus cogens ve erga omnes kavramları birbiriyle ilişkili iki kavram olsa da bu ilişkinin niteliği ve kapsamı tartışmalıdır ${ }^{69}$. Erga omnes yükümlülükler getiren kurallar ile jus cogens kurallar şeklinde belirlenen kurallar kategorik olarak birbirinden farklıdır ${ }^{70}$. Erga omnes yükümlülüklerin usule ilişkin olduğu değerlendirilirken jus cogens kuralların uluslararası hukukun esasıyla ilgili olduğu ifade edilmiştir ${ }^{71}$. Jus cogens kuralların uluslararası örf ve adet hukukunun uzun süreyle uygulanmasından kaynaklandı̆̆ ileri sürülürken erga omnes yükümlülüklerin uluslararası andlaşmalar ile de oluşturulabileceği kabul edilmektedir ${ }^{72}$.

Neticede bir uluslararası hukuk kuralının jus cogens nitelikte olduğu kabul edilirse erga omnes bir etki doğuracağı açıtır. Ne var ki, her erga omnes yükümlülüğün kaynağ jus cogens bir kuraldan kaynaklanmak durumunda değildir. Erga omnes yükümlülükler, uluslararası hukukun uluslararası hukuk kişileri arasındaki iki taraflı / karşılıklı ilişkilerden ibaret olmadığına ilişkin anlayıştan beslemektedir ${ }^{73}$. Jus cogens kurallar ile erga omnes yükümlülüklerin kapsamina dair teorik değerlendirmeler bu makalenin amaçladı̆̆ 1 kapsamın çok ötesinde bir incelemeyi gerektirmektedir. Ancak buna rağmen NSYA ile getirilen nükleer silah yasağının jus cogens bir kural olup olmadığı ve böylece erga omnes yükümlülükler getirip getirmediği hususunda değerlendirme yapılabilmesi mümkündür.

NSYA’nın içerdiği nükleer silahların tamamen yasaklanmasına ilişkin hükümlerin jus cogens bir kural olarak kabul edilmesi mümkün görünmemektedir. Üstelik jus cogens kurallar ortaya çıktığından beri belirsiz bir yapıdadır ve bu belirsizlik jus cogens kuralların neler olduğuna dair anlamlı bir tasnif yapılmasını engellemektedir ${ }^{74}$. Ancak nükleer silahların yasaklanmasına ilişkin kuralların jus cogens olarak kabul edilebileceğine dair hiçbir emare bulunmamaktadır. Dolayısıyla NSYA’ya taraf olmayan devletler bakımından nükleer silahların yasaklanması hukuki bir sonuç doğurmayacaktır.

\section{SONUÇ}

NSYA, uluslararası hukuk çerçevesinde nükleer silahları açıkça yasaklayan ilk uluslararası andlaşma olarak 2021 yılında yürürlüğe girmiştir. Bu gelişme, yaklaşık olarak 75 yıldır devam eden nükleer silahsızlanma çabaları dikkate alındığında önemli bir aşamadır. Üstelik NSYA’nın ortaya çıkışı ve imzalanması sürecinde uluslararası toplumun çeşitli katılımcılarının etkisinin bulunduğu görülmektedir. NSYA'nın hem bu farklılığı hem de insancıl silahsızlanma vurgusu nükleer silahsızlanmayı destekleyen pek çok kesim tarafından olumlu bir gelişme olarak görülmektedir.

Law Volume VII, Oxford University Press, Oxford 2012, p. 916.

69 Byers, Michael: "Conceptualising the Relationship between Jus Cogens and Erga Omnes Rules", Nordic Journal of International Law, 66, 1997, p. 211.

70 Picone, Paolo: "The Distinction between Jus Cogens and Obligations Erga Omnes", E. Cannizzaro (ed), The Law of Treaties Beyond the Vienna Convention, Oxford University Press, New York 2011, p. 414.

71 Akkutay, s. 216.

72 Byers, s. 239.

73 Frowein, s. 919.

74 Weatherall, Thomas: Jus Cogens: International Law and Social Contract, Cambridge University Press, Cambridge 2015, s. 200. 
Ne var ki, NSYA neticede bir uluslararası andlaşmadır ve onun normatif etkisi uluslararası hukuk çerçevesinde değerlendirilebilecektir.

Uluslararası hukukta nükleer silah kullanımının tamamen yasaklanmasına ilişkin bir örf ve adet hukuku kuralı bulunmamaktadır. Dolayısıyla NSYA nükleer silahları açıkça yasaklayan ilk ve tek uluslararası hukuk kaynağıdır. Bu andlaşma, sadece kendisine taraf olan devletleri bağlamakta ve pacta tertiis ilkesi gereğince üçüncü devletler üzerinde hüküm ve sonuç doğurmamaktadır. Makale kapsamında NSYẢnın herhangi bir biçimde üçüncü devletler üzerinde etkili olup olamayacağ araştırılmış ve böylece nükleer silahların yasaklanmasına ilişkin uluslararası hukuk çerçevesinde bir değerlendirmeye gidilmiştir. NSYA, objektif durum yaratan bir andlaşma olmadı̆̆ 1 gibi nükleer silahların yasaklanmasına ilişkin jus cogens bir kural da bulunmamaktadır. Dolayısıyla, NSYA erga omnes etkiye sahip bir düzenleme olmadığı için sadece kendisine taraf olan devletleri bağlamaktadır.

Nükleer silahsızlanma ve nükleer silahların yasaklanması konusunda uluslararası toplumda ciddi bir çaba söz konusudur ve bu girişimler NSYA ile sonuçlanmıştır. Andlaşmanın insancıl silahsızlanma şeklinde farklı bir yaklaşım ortaya koyması ve dünyadaki devletlerin çoğu tarafından kabul edilmesi önemli bir gelişmedir. Ancak nükleer silahların yasaklanması hususunda hukukun ya da daha doğru bir ifadeyle uluslararası hukukun imkânları sınırlıdır. Nükleer silahların tamamen yasaklanması için nükleer silah sahibi devletlerin iradesinin ve bu devletlerin bir araya gelerek oluşturdukları ortak savunma politikalarının uzlaştırılması gerekmektedir. Sonuç olarak NSYA nükleer silahsılanma çabaları bakımından başarılı bir adım olmakla birlikte uluslararası hukukun nükleer silahların tamamen yasaklanması sorununa tek başına çare bulabilmesi mümkün görünmemektedir.

\section{KAYNAKÇA}

\section{Kitaplar ve Makaleler}

Arman, Perçem: “2017 Nükleer Silahların Yasaklanması Antlaşması: Amaçladığını Başarabilir Mi?”, Dokuz Eylül Üniversitesi Hukuk Fakültesi Dergisi, Prof. Dr. Durmuş TEZCAN’a Armağan, 21(Özel Sayı), 2019, s. 1907-1947.

Akkutay, Berat Lale: Uluslararası Andlaşmaların Üçüncü Devletlere Etkisi, Adalet Yayınevi, Ankara 2020.

Aust, Anthony: Modern Treaty Law and Practice, 3. Edition, Cambridge University Press, London 2013.

Bagheri, Saeed: Uluslararası İnsancıl Hukuk ve Nükleer Silahlar, Adalet Yayınevi, Ankara 2015.

Byers, Michael: “Conceptualising the Relationship between Jus Cogens and Erga Omnes Rules”, Nordic Journal of International Law, 66, 1997, p. 211-239.

Datan, Merav / Scheffran, Jürgen: "The Treaty is Out of the Bottle: The Power and Logic of Nuclear Disarmament”, Journal for Peace and Nuclear Disarmament, 2(1), 2019, p. 114-132.

Denk, Erdem: “Bir Kitle İmha Silahı Olarak Nükleer Silahların Yasaklanmasına Yönelik Çabalar”, Ankara Üniversitesi SBF Dergisi, 66(3), 2011, s. 93-136.

Docherty, Bonnie: "A 'Light for All Humanity': the Treaty on the Prohibition of Nuclear Weapons and the Progress of Humanitarian Disarmament", Global Change, Peace \& Security, 30(2), 2018, p. 163-186.

Frowein, Jochen A: "Obligations Erga Omnes", R Wolfrum (ed), The Max Planck Encyclopedia of Public International Law Volume VII, Oxford University Press, Oxford 2012, p. 916-920. 
Gibbons, Rebecca Davis: “The Humanitarian Turn in Nuclear Disarmament and the Treaty on the Prohibition of Nuclear Weapons", the Nonproliferation Review, 25(1-2), 2018, p. 11-36.

Güneysu, Gökhan: Çevrenin Silahlı Çatışmalar Esnasında Korunması, Adalet Yayınevi, Ankara 2014.

Hanson, Marianne: “The Future of the NPT”, Australian Journal of International Affairs, 59(3), 2005, p. 301316.

Kadelbach, Stefan: "Nuclear Weapons and Warfare", R Wolfrum (ed), The Max Planck Encyclopedia of Public International Law Volume VII, Oxford University Press, Oxford 2012, p. 872-889.

Kaya, İbrahim: Uluslararası Hukukta Temel Belgeler, 4. Baskı, Seçkin Yayıncılık, Ankara 2020.

Öktem, Emre: Uluslararası Teamül Hukuku, Beta Yayınları, İstanbul 2013.

Pazarcı, Hüseyin: Uluslararası Hukuk Dersleri I. Kitap, Gözden Geçirilmiş 15. Bası, Turhan Kitabevi, Ankara 2021.

Pedrazzi, Marco: “The Treaty on the Prohibition of Nuclear Weapons: a Promise, a Threat or a Flop?", The Italian Yearbook of International Law Online, 27(1), 2018, p. 215-234.

Picone, Paolo: "The Distinction between Jus Cogens and Obligations Erga Omnes", E. Cannizzaro (ed), The Law of Treaties Beyond the Vienna Convention, Oxford University Press, New York 2011, p. 411-424.

Rietiker, Daniel: “New Hope for Nuclear Disarmament or 'Much Ado About Nothing?': Legal Assessment of the New "Treaty on the Prohibition of Nuclear Weapons" and the Joint Statement by the USA, UK, and France Following its Adoption., Harvard International Law Journal, 59, 2017, p. 22-32.

Romani, Carlos Fernández de Casadevante: “Objective Regime”, R. Wolfrum (ed), The Max Planck Encyclopedia of Public International Law Volume VII, Oxford University Press, Oxford 2012, p. 912-915.

Salerno, Francesco: “Treaties Establishing Objective Regimes”, E. Cannizzaro (ed), The Law of Treaties Beyond the Vienna Convention, Oxford University Press, New York 2011, p. 225-243.

Söyler, Yasin: "Barcelona Traction Davası ve Uluslararası Hukuka Etkisi”, Ankara Hacı Bayram Veli Üniversitesi Hukuk Fakültesi Dergisi, 19(3), 2015, s. 207-248.

Toluner, Sevin: “ ‘Objektif Hukuki Durum Yaratan Andlaşmalar' Kavramı Gerekli Midir?”, Milletlerarası Hukuk ve Milletlerarası Özel Hukuk Bülteni, 25(1-2), 2005, s. 519-580.

Tuzmukhamedov, Bakhtiyar: "Disarmament”, R Wolfrum (ed), The Max Planck Encyclopedia of Public International Law Volume III, Oxford University Press, Oxford 2012, p. 150-159.

Tütüncü, Ayşe Nur: "Nükleer Silâhların Kullanımının Yasaklanması Sorunu", Anadolu Üniversitesi Sosyal Bilimler Dergisi, 4(2), 2004, s. 9-26.

Uzun, Elif: "Milletlerarası Adalet Divanının Nükleer Silahların Tehdidi veya Kullanımının Meşruiyeti İle İlgili 1996 Tarihli İstişari Mütalaasına İnsancıl Hukuk Açısından Bir Bakış”, Erzincan Hukuk Fakültesi Dergisi, 7(3), 2003, s. 557-588.

Weatherall, Thomas: Jus Cogens: International Law and Social Contract, Cambridge University Press, Cambridge 2015.

\section{internet Kaynakları}

ABD, Birleşik Krallık ve Fransa’nın açılamaları: https://www.nti.org/learn/treaties-and-regimes/treaty-on-theprohibition-of-nuclear-weapons/ (07.03.2021).

Atom Enerjisinin Keşfi ile Ortaya Çıkan Sorunların Çözümü İçin Komisyon Kurulması, https://www.un.org/ga/ search/view_doc.asp?symbol=A/RES/1(I) (28.02.2021). Humanitarian Pledge, https://www.icanw.org/ history_of_the_tpnw (07.03.2021). 
Barcelona Traction, Light and Power Company, Limited, Judgment, I.C.J. Reports 1970, p. 3. https://www.icj-cij. org/public/files/case-related/50/050.197.00205-JUD-01-00-EN.pdf (20.03.2021).

International Campaign to Abolish Nuclear Weapons (ICAN), hakkında detaylı bilgi için: https://www.icanw. org/the_campaign (06.03.2021).

Legality of the Threat or Use of Nuclear Weapons, Advisory Opinion, I.C.J. Reports 1996, p. 226. https://www. icj-cij.org/public/files/case-related/95/095.199.60708-ADV-01-00-EN.pdf (03.03.2021).

Nuclear-Armed States, https://www.icanw.org/nuclear_arsenals (28.02.2021).

Nükleer Silahların Yasaklanması Andlaşması, https://undocs.org/A/CONF.229/2017/8 (07.03.2021).

Overview of TPNW, https://www.un.org/disarmament/wmd/nuclear/tpnw/ (07.03.2021).

Russia and Nuclear Weapons, https://www.nti.org/learn/countries/russia/nuclear/ (28.02.2021).

UAEA Statüsü, https://treaties.un.org/doc/Publication/UNTS/Volume\%20276/volume-276-I-3988-English.pdf (28.02.2021).

UN General Assembly, A/RES/70/48, https://www.un.org/en/ga/search/view_doc.asp?symbol=A/RES/70/48 (07.03.2021).

UN General Assembly, A/RES/70/33, https://undocs.org/pdf?symbol=en/a/res/70/33 (07.03.2021).

United Nations Office for Disarmament Affairs, https://www.un.org/disarmament/wmd/nuclear/ (26.02.2021).

United Nations Treaty Collection, https://treaties.un.org/Pages/ViewDetails.aspx?src=TREATY\&mtdsg no=XXVI-9\&chapter=26 (26.02.2021).

Vienna Convention on the Law of Treaties done at Vienna on 23 May 1969. Entered into force on 27 January 1980. United Nations, Treaty Series, vol. 1155, p. 331. https://legal.un.org/ilc/texts/instruments/english/ conventions/1_1_1969.pdf (11.03.2021). 